\title{
Delayed Hypersensitivity Responses of Guinea Pig and Rat to Angiostrongylus cantonensis Infection
}

\author{
Kentaro YOSHIMURA and Hiroko AIBA \\ Department of Parasitology, Juntendo University School of Medicine, Bunkyo-ku, Tokyo 113 \\ Mineo HAYASAKI \\ Department of Medicine and Parasitology, School of Veterinary Medicine, \\ Tokyo University of Agriculture and Technology, Fuchu-shi, Tokyo 183 \\ Hideko YOSHIDA \\ Department of Infectious Diseases, Azabu Veterinary College, \\ Fuchinobe, Sagamihara-shi, Kanagawa 229
}

(Received for publication September 6, 1976)

\begin{abstract}
Guinea pigs and rats infected with the Taiwanese strain of Angiostrongylus cantonensis were monitored for the evolution of delayed hypersensitivity (DH) responses by assessing macrophage migration inhibitory factor (MIF) and delayed-type skin reactivity. These animals were also examined for the production of hemagglutinating (IHA) and precipitating antibodies.

In guinea pigs, MIF resporse was consistently positive throughout 12 to 35 days postinfection. In fact, MIF production was shown by lymphoid cells from the cervical lymph nodes and spleen from infected animals. Delayed-type skin reactivity was correlated with the results of MIF assay. Contrarily, both IHA and precipitating antibodies were not detected in guinea pig sera throughout the course of infection. However, sera from both non-infected and infected guinea pigs yielded an immunologically non-specific precipitin band against $A$. cantonensis antigen.

In rats, MIF response, as measured by the direct method, was variable throughout 6 to 77 days postinfection and the MIF results did not necessarily agree with the dermal reactivity. However, similar assay by the indirect method using normal guinea pig macrophages as indicator cells demonstrated that MIF activity could be detected in the cervical lymph node cells obtained from rats on days 7 and 37, whereas MIF from the mediastinal lymph node cells was first detected on day 29 and most frequently shown at later stages of infection. Precipitating antibody was first detected in sera from an infected rat 6 days postinfection while IHA antibody occurred first on day 34 .

Histologically, dermal reaction of the infected guinea pigs indicated a pronounced infiltration of mononuclear cells in the dermis. In rats, however, little cellular infiltration was present in the upper or midzone of the dermis, although massive infiltrative lesions were predominant in the subcutaneous fat and muscle and the deeper connective tissue.

The present results suggest that $\mathrm{DH}$ is involved in immune responses of both guinea pigs and rats to $A$. cantonensis infection.
\end{abstract}

The presence of delayed hypersensitivity $(\mathrm{DH})$ or cell-mediated immunity has been reported in certain parasitic infections as reviewed by Soulsby [21] and Larsh and Weatherly [11]. However, little information is available on $\mathrm{DH}$ in the majority

広東住血線虫感染モルモットおよびラットに扣ける遅延型過敏症反応について：吉村堅太郎・合場広子（順天堂 大学医学部寄生虫学教室), 早䗁峉夫 (東京農工大学農学部家畜内科学教室), 吉田秀子 (麻布獣医科大学伝染病 学教室) 
of helminthic infections and its potential role in acquired or protective immunity to such parasitic infections.

In Angiostrongylus cantonensis infection, Yoshimura and Soulsby [27] and Yoshimura and Yamagishi [28] suggested the possible presence of $\mathrm{DH}$ in both normal (rat) and abnormal (guinea pig) hosts. However, these authors pointed out that more extensive study would be necessary for determining the existence of $\mathrm{DH}$ in $A$. cantonensis infection using a variety of parameters other than in vitro lymphocyte blastogenesis.

The purpose of the present study is to monitor the time-course development of $\mathrm{DH}$ responses in guinea pigs and rats infected with the Taiwanese strain of $A$. cantonensis; DH was assessed by the presence of macrophage migration inhibitory factor (MIF) and delayed-type skin reactivity both of which have been well known as in vitro and in vivo correlates of $\mathrm{DH}$. These animals were also examined for the production of hemagglutinating and precipitating antibodies.

\section{Materials and Methods}

A. cantonensis: The Taiwanese strain of this parasite was kindly supplied by Prof. T. Suzuki, Akita University, in February, 1975. The 3rd stage larvae were harvested from Biomphalaria glabrata snails which had been exposed to the lst stage larvae of the parasite by the method of Yoshimura and Soulsby [27].

Animal infections: Hartley strain guinea pigs weighing $246-408 \mathrm{~g}$ and Wistar strain rats, 220-456 $\mathrm{g}$ in weight, were used. Animal infections with $A$. cantonensis were performed as previously described $[27,28]$.

Antigen: Phosphate buffered saline (PBS; pH 7.2) extract of $A$. cantonensis adult worms (Hawaiian strain) was prepared as previously described [27] and used as antigen. The protein concentration of the antigen was determined by the method of Lowry et al. [12].

MIF assay: Peritoneal exudate cells (PEC) were harvested from normal or infected animals sacrificed
3 to 5 days after intraperitoneal injection of $10 \mathrm{~m} l$ of sterile liquid paraffin. The peritoneal exudate was washed from the abdominal cavity with $80 \mathrm{~m} l$ of cold heparinized ( 5 units $/ \mathrm{m} l$ ) Hanks' balanced salt solution (HBSS; Nissui Seiyaku, Co., Tokyo), cells were centrifuged at $250 \times \mathrm{G}$ for $10 \mathrm{~min}$ at $4^{\circ} \mathrm{C}$ and the cell pellet washed once with HBSS and then washed twice with TC 199 (Nissui Seiyaku Co., Tokyo) containing $50 \mu \mathrm{g}$ of kanamycin $/ \mathrm{m} l$.

The agarose migration assay of MIF activity was performed essentially as described previously [8]. One microliter of $0.8 \%$ (w/v) Sea Plaque Agarose (Marine Colloids, Rockland, ME) in distilled water was dispensed onto the central area of each tissue culture chamber (Lab-Tek Products, Naperville, IL) and the agarose drops were allowed to dry. PEC were suspended to a $25 \%(\mathrm{v} / \mathrm{v})$ concentration in TC 199 supplemented with $15 \%$ fetal bovine serum (FBS; Flow Laboratories, Rockville, MD) and containing $0.2 \%$ agarose $(\mathrm{w} / \mathrm{v})$. Two $\mu l$ of this cell suspension were placed over the precoated area of each chamber, and the chambers were cooled at $4^{\circ} \mathrm{C}$ for $5 \mathrm{~min}$. Each chamber containing a drop of gelled agarose-PEC suspension was filled with $0.3 \mathrm{~m} l$ of medium, and the chambers were incubated at $37^{\circ} \mathrm{C}$ under $5 \% \mathrm{CO}_{2}-95 \%$ air for $48 \mathrm{hr}$.

On the basis of preliminary studies on the optimum antigen concentration, guinea pig PEC were assayed in medium with or without antigen $(60 \mu \mathrm{g}$ or $100 \mu \mathrm{g}$ protein/chamber) and in medium containing bovine albumin (100 $\mu \mathrm{g} /$ chamber) (BA; Daiichi Pure Chemicals, Co., Tokyo). Similarly, rat PEC were assessed in medium with or without antigen $(30 \mu \mathrm{g}$ or $50 \mu \mathrm{g})$ and in medium with BA $(50 \mu \mathrm{g})$.

Migration of PEC from the agarose droplets was measured at 24 and $48 \mathrm{hr}$ by the method of Harrington and Stastny [8]; migration ratio (MR) was calculated by dividing the migration distance of the assay containing antigen or $\mathrm{BA}$ by that of the control.

MIF productions by lymphoid cells (LC) from the infected guinea pigs or rats, when incubated with specific antigen in vitro, were analyzed by the indirect method of MIF assay employing PEC from normal guinea pigs as indicator cells. In guinea pigs, LC were obtained from the cervical lymph nodes and spleen while those in rats were from the cervical or mediastinal lymph nodes, and peripheral blood.

LC were obtained from the animals by teasing the above described lymphoid organs in TC 199, centrifuging the cells at $250 \times \mathrm{G}$ for $10 \mathrm{~min}$ at $4^{\circ} \mathrm{C}$ and washing once with TC 199. On the other hand, $5 \mathrm{ml}$ of anticoagulated rat peripheral blood were 
collected by heart puncture and the lymphocytes were isolated by centrifugation of the blood in Ficoll-Conray gradients [3]. Each culture tube measuring $10 \times 105 \mathrm{~mm}$ contained $50 \times 10^{6} \mathrm{LC}$ suspended in $2.5 \mathrm{ml}$ of TC 199 supplemented with $5 \%$ FBS $\left(20 \times 10^{6} \mathrm{LC} / \mathrm{ml}\right)$. The number of rat peripheral blood lymphocytes cultured, however, varied from $0.3 \times 10^{6}$ to $12.5 \times 10^{6} / \mathrm{m} l$ of culture medium (mean: $5.8 \times 10^{6} / \mathrm{m} l$ ) since sufficient numbers of lymphocytes could not be harvested. LC cultures were incubated with and without antigen $(160 \mu \mathrm{g}$ protein $/ \mathrm{m} l$ of medium for guinea pig LC and $80 \mu \mathrm{g} / \mathrm{m} l$ for rat $\mathrm{LC}$ ). Medium alone with and without antigen was similarly incubated to serve as a control. Cultures containing guinea pig LC were incubated for $24 \mathrm{hr}$ at $37^{\circ} \mathrm{C}$ under $5 \% \mathrm{CO}_{2^{*}}$ $95 \%$ air whereas those containing rat LC were incubated for $48 \mathrm{hr}$ at the same condition. After incubation, LC were removed by centrifuging at $250 \times \mathrm{G}$ for $10 \mathrm{~min}$, and the supernatants were supplemented with $10 \%$ FBS. These supernatants were assayed for MIF activity against normal guinea pig PEC.

Dermal reactivity: Both normal and infected animals to be used for MIF assay were clipped on the abdomen and injected intradermally with $0.1 \mathrm{ml}$ of antigen containing $20 \mu \mathrm{g}, 40 \mu \mathrm{g}$ or $80 \mu \mathrm{g}$ protein each. A control site was injected with $0.1 \mathrm{~m} l$ of PBS. At $44 \mathrm{hr}$ later, four sites of the injected areas were removed and fixed in $10 \%$ neutral formalin. The specimens were dehydrated, embedded in paraffin, cut and, sections were stained with hematoxylin and eosin. Sections were histopathologically examined for qualitative and quantitative differences in cellular infiltration in the dermis and subcutaneous tissue.

Sera: The guinea pigs and rats were bled by the ophthalmic venous plexus puncture under ether anesthesia. After the blood had clotted, serum was separated by centrifugation and stored at $-20^{\circ} \mathrm{C}$ until use.

Indirect hemagglutination (IHA) test: IHA test was performed by the method of Kamiya and Tanaka [9].

Gel-diffusion technique: Double-diffusion was done by the method of Ouchterlony [15], using $1.2 \%$ agar (Difco Special Agar-Noble) in veronal buffer ( $\mathrm{pH} 8.6 ; \mu=0.05$ ) on $26 \times 76 \mathrm{~mm}$ glass slides. The depth of the agar was approximately $2.0 \mathrm{~mm}$. Precipitin bands were allowed to develop overnight at room temperature and for additional $48 \mathrm{hr}$ at $4^{\circ} \mathrm{C}$. Slides were then washed for $7 \mathrm{~g} \mathrm{hr}$ in several changes of $0.85 \%$ saline solution and dried under filter paper, prior to staining with an aqueous solution of amido-black $10 \mathrm{~B}$ in $90 \%$ methanol and
$10 \%$ acetic acid. A similar mixture of methanol and acetic acid was used to remove excess stain, before the slides were dried.

Antigen for gel-diffusion analysis was used at a concentration of $32 \mathrm{mg}$ protein $/ \mathrm{m} l$.

Immunoelectrophoresis was performed according to the micromethod of Scheidegger [19], using the above described agar plate. A constant current of $1.25 \mathrm{~mA} / \mathrm{cm}$ width of agar gel was maintained for $160 \mathrm{~min}$ using filter paper wicks, and precipitin bands were allowed to develop as described above. The drying and staining procedure was analogous to the above.

Sephadex G-200 gel filtration: Gel filtration chromatography on normal guinea pig serum was carried out according to the method described by Yoshimura and Yamagishi [29]. Five to 6 tubes beneath the 1st (IgM), 2nd (IgG) and 3rd (albumin) peaks were pooled respectively and concentrated to a $1 / 20$ to $1 / 24$ of the original volume. The resulting three fractions were used for double-diffusion analysis against the worm antigen.

Absorption of normal guinea pig serum with anti-guinea pig IgG serum: Pooled normal guinea pig serum was mixed with an appropriate volume of rabbit-anti-guinea pig IgG serum (R-anti-GPIgG serum; Miles Laboratories, Inc., Kankakee, IL) and incubated at $37^{\circ} \mathrm{C}$ for $2 \mathrm{hr}$, and then overnight at $4^{\circ} \mathrm{C}$. The serum was then centrifuged at $5500 \times \mathrm{G}$ for $30 \mathrm{~min}$ and the resulting absorbed serum was used for double-diffusion analysis against $A$. cantonensis antigen. Gel-diffusion was also performed on this serum to ensure that absorption was complete.

\section{Results}

\section{Guinea pigs}

All guinea pigs were infected per os with 41-88 (mean: 70) A. cantonensis 3rd stage larvae.

1. MIF assay: In normal guinea pigs, only 2 animals ( $\mathrm{N}-1$ and $\mathrm{N}-4$ ) yielded a comparatively low MR value of 0.79 against $100 \mu \mathrm{g}$ of antigen but the remainder presented higher values against both $60 \mu \mathrm{g}$ of antigen and $100 \mu \mathrm{g}$ of BA (Table 1). Although a single infected guinea pig (I-2) produced an extraordinarily low MR value (0.73) against BA (Table 1), the remaining animals yielded higher MR values than 0.83 (I-6). On the basis of these results, MR 
Table 1. The evolution of cellular and humoral immune responses during the course of Angiostrongylus cantonensis infection in guinea pigs

\begin{tabular}{|c|c|c|c|c|c|c|c|}
\hline \multirow{4}{*}{$\begin{array}{l}\text { Animal } \\
\text { No. }\end{array}$} & \multirow{4}{*}{$\begin{array}{c}\text { Days } \\
\text { postinfection }\end{array}$} & \multicolumn{6}{|c|}{ Immune responses } \\
\hline & & \multicolumn{4}{|c|}{ Cellular } & \multicolumn{2}{|c|}{ Humoral } \\
\hline & & \multicolumn{3}{|c|}{ Migration ratios in MIF assay } & \multirow{2}{*}{ Skin test $\dagger$} & \multirow{2}{*}{$\begin{array}{l}\text { Reciprocal } \\
\text { IHA titer }\end{array}$} & \multirow{2}{*}{$\begin{array}{l}\text { No. of } \\
\text { precipitin } \\
\text { bands }\end{array}$} \\
\hline & & $\mathrm{Ag} 100 \mu \mathrm{g}$ & $\mathrm{Ag} 60 \mu \mathrm{g}$ & BA $100 \mu \mathrm{g}$ & & & \\
\hline$N 1$ & 0 & 0.79 & ND & ND & ND & 0 & $0^{*}$ \\
\hline N 2 & 0 & 0.93 & 0.99 & 1.04 & ND & 0 & $0^{*}$ \\
\hline N 3 & 0 & 0.90 & 0.94 & 0.96 & - & 0 & $0^{*}$ \\
\hline$N 4$ & 0 & 0.79 & 0.84 & 0.85 & - & 0 & $0^{*}$ \\
\hline N 5 & 0 & 0.90 & 0.98 & 0.90 & - & ND & ND \\
\hline N 6 & 0 & 0.99 & 1.02 & 1.02 & - & 0 & $0^{*}$ \\
\hline N 7 & 0 & 0.81 & 0.91 & 1.06 & ND & 0 & $0^{*}$ \\
\hline N 8 & 0 & 0.89 & ND & ND & ND & ND & ND \\
\hline N9 & 0 & 0.87 & 1.00 & 1.05 & ND & ND & ND \\
\hline N 10 & 0 & 0.88 & 1.00 & 1.02 & ND & ND & ND \\
\hline Mean $\pm S D$ & & $0.88 \pm 0.06$ & $0.96 \pm 0.06$ & $0.99 \pm 0.08$ & & & \\
\hline 11 & 5 & 0.67 & ND & ND & ND & 0 & 0* \\
\hline 12 & 5 & 0.93 & 0.96 & 0.73 & - & 0 & $0^{*}$ \\
\hline 13 & 12 & 0.70 & 0.95 & 0.98 & ND & ND & ND \\
\hline 14 & 12 & 0.68 & 0.82 & 0.98 & ND & ND & ND \\
\hline 15 & 18 & 0.46 & 0.65 & 0.94 & + & 0 & $0 *$ \\
\hline 16 & 18 & 0.54 & 0.63 & 0.83 & + & 0 & $0^{*}$ \\
\hline 17 & 19 & 0.76 & 0.78 & 0.94 & + & 0 & O* \\
\hline 18 & 23 & 0.33 & 0.67 & 0.87 & ND & ND & ND \\
\hline 19 & 25 & 0.41 & 0.39 & 0.90 & + & 0 & $0^{*}$ \\
\hline 110 & 25 & 0.22 & 0.31 & 0.97 & ND & ND & ND \\
\hline 111 & 26 & 0.32 & 0.51 & 0.85 & + & 0 & $0^{*}$ \\
\hline 112 & 29 & 0.66 & 0.77 & 0.98 & ND & ND & ND \\
\hline 113 & 35 & 0.50 & 0.52 & 0.95 & + & 0 & $0^{*}$ \\
\hline
\end{tabular}

Remarks.

MIF: Migration inhibitory factor. Ag: Antigen. BA: Bovine albumin. $\dagger$ : Histopathologically determined by the presence of mononuclear cell infiltrates. + : Positive. -: Negative. IHA: Indirect hemagglutination test. N: Non-infected. I: Infected. SD: Standard deviation. ND: Not done. *: A single immunologically non-specific band was observed (see also text).

Table 2. Migration inhibition of normal peritoneal exudate cells by supernatants of infected guinea pig lymphoid cells cultured with Angiostrongylus cantonensis adult worm antigen

\begin{tabular}{ccccc}
\hline \multirow{2}{*}{ Animals } & $\begin{array}{c}\text { Days } \\
\text { postinfection }\end{array}$ & $\begin{array}{c}\text { Cervical lymph } \\
\text { node cells* }\end{array}$ & Splenic cells* & Control medium** \\
\hline 1 & 23 & 0.42 & ND & 0.96 \\
2 & 29 & 0.34 & 0.67 & 0.83 \\
\hline
\end{tabular}

Remarks.

*: Number of lymphoid cells cultured was $50 \times 10^{6}$ in $2.5 \mathrm{ml}$ of culture medium $\left(20 \times 10^{6} / \mathrm{ml}\right)$.

**: Control medium was incubated in the same manner as lymphoid cells but contained no cells.

ND: Not done. 
value below 0.8 was considered significant in this study. This criterion was also suited for use in rat MIF assay (Tables 3 and 4).

All infected guinea pigs, except for a single animal (I-2) on day 5, presented positive MR values against $100 \mu \mathrm{g}$ of antigen stimulation throughout 5 to 35 days postinfection (Table 1). For $60 \mu \mathrm{g}$ of antigen stimulation, however, three animals (I-2 to I-4) gave negative MIF responses 5 to 12 days postinfection but at later stages, the remainder was all positive (Table 1).

In fact, MIF production was shown by LC from the cervical lymph nodes and spleen from infected animals on days 23 and 29 of infection (Table 2).

2. Dermal reactivity: In control animals, significant cellular reactions could not be seen in any of skin sites injected with PBS (Fig. 1-A), $20 \mu \mathrm{g}, 40 \mu \mathrm{g}$ or $80 \mu \mathrm{g}$ (Fig. 1-B) of antigen (see also Table 1).

In infected animals, there was a striking parallelism between dermal reactivity and MIF responses (Table 1); all animals examined throughout 18 to 35 days postinfection were positive for dermal reactivity. The PBS injected control site usually presented no cellular reaction but occasionally demonstrated a very slight reaction consisting of some polymorphonuclear leukocytes (PMN) in the dermis and subcutaneous tissue (Fig. 1-C). In contrast, the antigen injected sites were characterized by the predominant mononuclear cell infiltration in the dermis, this consisting of lymphocytes and macrophages. Such cellular reactions, coupled with perivascular cuffing, were also evident in the subcutaneous tissue (Fig. 1-D). The foci of mononuclear cell infiltrates were occasionall $y$ accompanied by a minimal infiltration of some eosinophils.

There was no significant qualitative and quantitative differences in cellular infiltra- tion among skin lesions injected with various protein concentrations of the antigen.

3. Antibody productions: IHA antibody was not detected in both control and infected guinea pigs (Table 1). In contrast, gel-diffusion revealed that sera from both control and infected animals yielded a single weak precipitin band against $A$. cantonensis antigen (Fig. 3). However, this band usually disappeared or markedly faded during the process of washing gels in several changes of saline solution. For the purpose of determining the serum fraction responsible for this band, a pooled normal guinea pig serum was applied to Sephadex G-200 column and each of the concentrated fractions beneath the 1st (Ig M), 2nd (IgG) and 3rd (albumin) peaks was tested by double-diffusion. The results indicated that the particular precipitin band occurred between fraction beneath the 3 rd peak and $A$. cantonensis antigen. Thus, an alternative test was performed to define whether or not the serum fraction is concerned with the fragments of IgG immunoglobulin class; normal guinea pig serum previously absorbed with R-antiGP-IgG serum was used for double-diffusion against the worm antigen. The results demonstrated that the particular band still occurred between the absorbed serum and the antigen, indicating that the serum fraction responsible for this band was not associated with the fragments of IgG. Rats

1. MIF assay: The rats were exposed to 53-63 (mean: 58) larvae of $A$. cantonensis, and used for the direct assay of MIF activity.

The differential cell counts on rat PEC were done on Giemsa-stained specimens of 2 normal and 4 infected animals, revealing that only 44 to $78 \%$ (mean: $55 \%$ ) of PEC populations were mononuclear cells and 
Table 3. The evolution of cellular and humoral immune responses during the course of Angiostrongylus cantonensis infection in rats

\begin{tabular}{|c|c|c|c|c|c|c|c|}
\hline \multirow{4}{*}{$\begin{array}{l}\text { Animal } \\
\text { No. }\end{array}$} & \multirow{4}{*}{$\begin{array}{c}\text { Days } \\
\text { postinfection }\end{array}$} & \multicolumn{6}{|c|}{ Immune responses } \\
\hline & & \multicolumn{4}{|c|}{ Cellular } & \multicolumn{2}{|c|}{ Humoral } \\
\hline & & \multicolumn{3}{|c|}{ Migration ratios in MIF assay } & \multirow{2}{*}{ Skin test* } & \multirow{2}{*}{$\begin{array}{l}\text { Reciprocal } \\
\text { IHA titer }\end{array}$} & \multirow{2}{*}{$\begin{array}{l}\text { No. of } \\
\text { precipitin } \\
\text { bands** }\end{array}$} \\
\hline & & $\mathrm{Ag} 50 \mu \mathrm{g}$ & $\mathrm{Ag} 30 \mu \mathrm{g}$ & BA $50 \mu \mathrm{g}$ & & & \\
\hline$N 1$ & 0 & 0.96 & 1.07 & 0.96 & - & 0 & 0 \\
\hline N 2 & 0 & 0.95 & 1.05 & 0.90 & ND & ND & ND \\
\hline N 3 & 0 & 1.13 & 1.19 & 0.99 & - & 0 & 0 \\
\hline$N_{4}$ & 0 & 0.98 & 0.93 & 0.90 & - & 0 & 0 \\
\hline N 5 & 0 & 0.90 & ND & ND & ND & 0 & 0 \\
\hline N 6 & 0 & 1.02 & 1.10 & 0.98 & - & 0 & 0 \\
\hline Mean & & 0.99 & 1.07 & 0.95 & & & \\
\hline 11 & 6 & 0.83 & 0.88 & 0.85 & - & 0 & 5 \\
\hline 12 & 15 & 0.63 & 0.69 & 0.80 & ND & ND & ND \\
\hline 13 & 15 & 0.29 & 0.37 & 0.95 & ND & ND & ND \\
\hline 14 & 20 & 0.73 & 0.73 & 1.03 & ND & 0 & 5 \\
\hline 15 & 20 & 0.36 & 0.64 & 1.04 & \pm & 0 & 6 \\
\hline 16 & 34 & 1.05 & 1.05 & 1.07 & + & 128 & 8 \\
\hline 17 & 35 & 0.84 & 0.86 & 0.82 & + & 32 & 6 \\
\hline 18 & 37 & 1.04 & 1.02 & 1.04 & + & 4096 & 5 \\
\hline 19 & 48 & 0.63 & 0.73 & 1.06 & - & 512 & 6 \\
\hline 110 & 49 & 0.67 & 0.74 & 1.30 & + & 2048 & 6 \\
\hline 111 & 49 & 0.45 & 0.47 & 0.92 & + & 2048 & ND \\
\hline 112 & 63 & 0.88 & 0.94 & 1.05 & + & 8192 & 8 \\
\hline 113 & 77 & 1.36 & 1. 24 & 1.03 & \pm & 4096 & ND \\
\hline
\end{tabular}

Remarks.

MIF: Migration inhibitory factor. Ag: Antigen. BA: Bovine albumin. *: Histopathologically determined by the presence of mononuclear cell infiltrates. IHA: Indirect hemagglutination test. **: Determined by immunoelectrophoretic analysis. ND: Not done. t: Positive. -: Negative. 土: Doubtful.

the remainder was PMN. The direct assay of MIF activity was performed on these PEC (Table 3). Control rats were negative for MIF response against both $\mathrm{BA}$ and antigen stimulations. Conversely, seven infected rats on days $15,20,48$ and 49 yielded positive $\mathrm{MR}$ values against antigen stimulation, although six infected rats on days $6,34,35,37,63$ and 77 were negative (Table 3). All infected rats presented negative MIF responses against BA stimulation throughout 6 to 77 days postinfection.

Subsequently, the indirect assay of MIF activity was carried out on rats infected with 59-60 larvae per rat. In control ani- mals, no MIF production was shown by LG (Table 4). In contrast, the cervical lymph node cells from 3 infected rats on days 7 and 37 showed positive MIF production. Similarly, $71 \%(5 / 7)$ of infected animals examined at 29 to 51 days of infection yielded MIF in their mediastinal lymph node cells (Table 4). As far as the present investigations are concerned, however, peripheral blood lymphocytes were all negative for MIF production throughout the course of experiments.

2. Dermal reactivity: Skin reactivity of control rats was all negative (Table 3). Dermal reactivity of infected rats did not necessarily coincide with MIF responses, as 
Table 4. Migration inhibition of normal guinea pig peritoneal exudate cells by supernatants of infected rat lymphoid cells cultured with Angiostrongylus cantonensis adult worm antigen

\begin{tabular}{|c|c|c|c|c|c|c|}
\hline \multirow{2}{*}{\multicolumn{2}{|c|}{$\begin{array}{l}\text { Animal } \\
\text { No. }\end{array}$}} & \multirow{2}{*}{$\begin{array}{c}\text { Days } \\
\text { postinfection }\end{array}$} & \multicolumn{4}{|c|}{ Migration ratios } \\
\hline & & & Cervical LNC* & \multirow{2}{*}{$\frac{\begin{array}{c}\text { Mediastinal } \\
\text { LNC* }\end{array}}{\text { ND }}$} & \multirow{2}{*}{$\begin{array}{l}\mathrm{PBL}^{* *} \\
0.95\end{array}$} & \multirow{2}{*}{$\frac{\begin{array}{c}\text { Control } \\
\text { medium }\end{array} * * *}{1.20}$} \\
\hline$N$ & 1 & 0 & 0.95 & & & \\
\hline$N$ & 2 & 0 & 1.06 & 1.00 & 1.11 & 1.07 \\
\hline$N$ & 3 & 0 & 0.96 & 1.09 & 1.00 & 1.04 \\
\hline$N$ & 4 & 0 & 0.89 & 0.81 & 1.10 & 1.02 \\
\hline$N$ & 5 & 0 & ND & 0.79 & 0.97 & 0.87 \\
\hline \multicolumn{2}{|c|}{ Mean } & & 0.97 & 0.92 & 1.03 & 1.04 \\
\hline \multicolumn{2}{|c|}{11} & 7 & 0.84 & 1.04 & 0.91 & 1.20 \\
\hline 1 & 2 & 7 & 0.59 & ND & 0.96 & 1.20 \\
\hline 1 & 3 & 14 & 0.90 & 0.88 & 1.04 & 1.07 \\
\hline 1 & 4 & 14 & 0.91 & 0.91 & 0.94 & 1.07 \\
\hline 1 & 5 & 29 & 0.81 & 0.30 & 1.02 & 1.04 \\
\hline 1 & 6 & 31 & 0.92 & 0.76 & 0.85 & 1.02 \\
\hline 1 & 7 & 31 & ND & 0.70 & 0.88 & 1.02 \\
\hline 1 & 8 & 37 & 0.67 & 0.49 & 0.90 & 1.00 \\
\hline \multicolumn{2}{|c|}{19} & 37 & 0.55 & 0.80 & 1.24 & 1.00 \\
\hline \multicolumn{2}{|c|}{110} & 51 & ND & 0.71 & 1.00 & 0.87 \\
\hline \multicolumn{2}{|c|}{111} & 51 & ND & 0.88 & 0.90 & 0.87 \\
\hline \multicolumn{2}{|c|}{$\begin{array}{l}\text { LNC: Lymph } \\
\text { cultured was } \\
\text { blood lympho } \\
\left(10^{6} / \mathrm{m} l\right) \text {. }\end{array}$} & $\begin{array}{l}\text { node cells. } \\
50 \times 10^{6} \text { in } 2 . \\
\text { cytes cultured } \\
* * * \text { : Control } \\
\text { lls. N: Non-in }\end{array}$ & $\begin{array}{l}\mathrm{BL} \text { Peripheral } \\
\mathrm{ml} \text { of culture } \\
\text { aried from } 0.3 \times \\
\text { edium was incul } \\
\text { cted. 1: Infect }\end{array}$ & $\begin{array}{l}\text { od lymphocy } \\
\text { ium } 120 \times 10^{6} \\
6 \text { to } 12.5 \times 1 \\
\text { d in the sam } \\
\text { ND: Not d }\end{array}$ & $\begin{array}{l}* \text { : Nun } \\
* * \text { : } \\
\text { of cultu } \\
\text { iner as }\end{array}$ & $\begin{array}{l}\text { lymphoid cells } \\
\text { of peripheral } \\
\text { m Imean: } 5.8 \\
\text { cells but con- }\end{array}$ \\
\hline
\end{tabular}

assessed by the direct method; 4 rats (I-6 to I-8, and I-12) with negative MIF activity were skin-test positive and conversely, a single rat (I-9) with positive MIF response was negative for skin reactivity.

Histologically the control rat generally presented no significant cellular reactions at the skin sites injected with both PBS and worm antigens (Figs. 2-A and 2-B). In infected animals, the PBS injected site usually gave no cellular infiltration but occasionally showed a very slight infiltration of mononuclear cells in the dermis, subcutaneous tissue (Fig. 2-C) and in the connective tissue underlying the muscle. To the contrary, the antigen injected sites were characterized by the presence of both diffuse infiltrates and perivascular collections of mononuclear cells, with a minimal infiltration of eosinophils, in the subcutaneous tissue, especially, in fat and panniculus, and in the connective tissue underlying the muscle (Fig. 2-D). However, it is of interest to note that such cellular infiltrations were absent or minimal in the dermis. The degree of cellular reactions appeared to be independent of antigen doses injected.

3. Antibody productions: IHA antibody was first detected on day 34 and thenceforth, consistently found in sera from all infected rats until the end of the study (Table 3). The production of precipitating antibody was noted in earlier stages of infection, i.e., a single rat serum examined as early as 6 days postinfection yielded 5 precipitin bands against the worm antigen 
and since then, all individuals were positive for precipitin reactions (Table 3). Number of precipitin bands recovered varied between 5 and 8 (Table 3). All control rats were negative for both IHA and precipitating antibodies.

\section{Discussion}

Inhibition of macrophage migration from glass capillary or agarose droplet has been well known as an in vitro correlate of $\mathrm{DH}[2,5,7,8]$. This is also true for the present study since antigen specific MIF responses of the infected guinea pigs coincided with the dermal reactivity (Table 1). These experiments and the previous results of in vitro lymphocyte blastogenesis [28] clearly show that DH would play an important role in immune responses of $A$. cantonensis infected guinea pigs. In this animal, the larval development is approximately identical with that in the rat until about 20 days postinfection, but the larvae cease to develop about 25 to 30 days postinfection and die shortly [13,26]. Our study indicated that MIF responses could be noted in a single guinea pig as early as 5 days postinfection, increasing at later stages than day 18 and persisting until day 35. Besides, MIF production did occur in LG from both the cervical lymph nodes and spleen the former of which had stronger activity than the latter (Table 2). All of these data are suggestive that $\mathrm{DH}$ might be associated with the arrest of larval development or larval death occurring in the brain tissue.

Both IHA and precipitating antibodies could not be detected in sera from infected guinea pigs (Table 1). The absence of IHA antibody production was also described previously by Yoshimura and Yamagishi [28]. As far as the immune responses of infected guinea pigs are moni- tored by using the PBS extract of $A$. cantonensis adult worms as antigen, it can be concluded that DH may be induced more easily than IgM or IgG antibody productions and such immune responses are distinct from those of infected rats (see below).

It is of interest to note that the guinea pig possessed a particular serum component reacting with $A$. cantonensis PBS extract and yielding a non-specific precipitin band in agar-gel diffusion (Fig. 3). Our study clearly indicates that the responsible serum component would be concerned with neither immunoglobulin classes nor their fragments. Consequently, it can be surmised that a certain serum component loosely combines with some constituent of the antigen to form the non-specific precipitin band.

Yoshimura and Yamagishi [28] monitored in vitro lymphocyte blastogenic responses of guinea pigs infected with a large dose (198-218 larvae) of the Hawaiian strain of $A$. cantonensis until 47 days postinfection. In the present study, however, guinea pigs exposed to a smaller dose (4188 larvae) of the Taiwanese strain usually died before day 35 as previously described by Yamashita et al. [26]. This may be indicative of pathogenic differences between two strains of the parasite. However, it is still undefined whether the differences in pathogenicity are due to so-called geographic strain differences or due to the occurrence of virulent changes of the Hawaiian strain during its laboratory maintenance by passages through an experimental intermediate host (B. glabrata snails) and the rat for more than 10 years.

The results of the direct assay of MIF activity in infected rats were variable and did not agree with the skin reactivity (Table 3). Similarly, the data obtained from the indirect assay also varied signifi- 
cantly throughout the course of infection (Table 4). However, it was revealed by the latter assay that almost all animals $(86 \%=6 / 7)$ examined 29 to 51 days postinfection were positive for MIF activity in either the cervical or mediastinal lymph node cells. Thus, the dermal reactivity as shown in Table 3 may be analogous to the MIF responses detected by the indirect assay (Table 4) rather than those by the direct one (Table 3). These facts imply that the direct assay of MIF activity might not be suited for use in detecting $\mathrm{DH}$ in rats. As described above, rat PEG contained a lot of PMN. In man, Rocklin [17] reported that leukocyte inhibitory factor (LIF) was present as a lymphokine distinct from MIF, having unique physico-chemical properties, and that the indicator cells for this particular lymphokine were PMN but not macrophages. If a similar type of lymphokine should be produced by rat LC, it would be possible that migration inhibition of rat PEC observed in the present study was not due to MIF alone but due to LIF like factor alone or due to both factors. Further studies have to be done to determine this possibility since our results are closely associated with those of Kaltreider et al. [10] who reported that LIF response did not parallel the dermal reactivity, although Astor et al. [1] observed a striking parallelism between LIF responses and skin reactivity.

Nevertheless, our data clearly indicate that, when being incubated with the specific antigen, the LC from infected rats elaborate a MIF which is capable of inhibiting the migration of heterologous (guinea pig) PEG as previously described in $\operatorname{man}[18,22]$.

In rats, a significant in vitro lymphocyte blastogenic response has been found only in the cervical lymph node cells 1 to 4 weeks postinfection [27]. Thus, it is especially noteworthy that MIF production was shown by LC from the mediastinal lymph nodes in $71 \%$ of infected rats examined at later stages than 29 days postinfection, which is the time when young adult worms in the brain have just reached the lung [13]. Sequential appearance of MIF responses in two lymph nodes implies that $\mathrm{DH}$ responses in rats are local and follow the course of the parasite infection, in that the cervical lymph nodes are the first to respond and this is followed by the mediastinal lymph nodes.

As far as the present study is concerned, no MIF responses could be noted in the peripheral blood lymphocytes. The reason for this phenomenon is still unknown but it is probable that the number of peripheral lymphocytes used was not sufficient enough to respond when compared with the lymph node cells.

Histopathological observations on dermal reaction of infected guinea pigs at $44 \mathrm{hr}$ after antigen injection are identical with those of the typical delayed-type dermal reaction [23], and this is also supported by the results of MIF responses of the animals (Table 1). In rats, however, it would be quite probable that skin reactions at $44 \mathrm{hr}$ were not delayed-type but Arthus-type or overlapping of both types, since the presence of circulating (IHA and precipitating) antibodies was notable. Nevertheless, dermal reactions of $A$. cantonensis infected rats are comparable to those of the rats immunized with killed tubercle bacilli and later skin-tested with tuberculin $[6,25]$.

It is also of interest to note that histological features of dermal reactions, i.e., distribution of mononuclear cell infiltrates, were quite different between guinea pigs and rats. This is considered due to animal difference; Flax and Waksman [6] described 
that, in rats, the lack of mononuclear cell infiltration in the upper or midzone of the dermis could be attributed to the absence of distribution of larger calibered vessels in the particular skin areas.

In rats, precipitating antibody could be detected in sera earlier than IHA antibody (Table 3). It appears that the number of precipitin bands formed is correlated with neither the number of larvae inoculated [20] nor days of infection.

In conclusion, the present study is indicative that $\mathrm{DH}$ could be established in both guinea pigs and rats infected with $A$. cantonensis, and that there is a significant difference in kinetics of development of im: mune response to $A$. cantonensis between the two hosts. In guinea pigs, $\mathrm{DH}$ can be induced more readily than circulating antibodies and persists throughout the course of infection. In contrast, induction of such antibodies in rats is more prominent than that of $\mathrm{DH}$, the presence of which is not consistent. Recently, it has been well established that susceptibility or resistance of mice to pathogenic agents such as murine lymphocytic choriomeningitis virus [14], Leishmania donovani [4], Salmonella typhimurium [16] and Trichuris muris [24] differed significantly among the strains of mice, and that there existed a certain relationship between their resistance and immune responses to the particular pathogen. Besides, it has been surmised that resistance would be under genetic control by specific immune response gene(s) of the host against the antigen(s) derived from such a pathogen. In view of this, immunogenetic studies using various strains of inbred rats are now in progress to determine the possible relationship between host immune responses and susceptibility to $A$. cantonensis.
Acknowledgments: We are indebted to Professor H. Oya, Juntendo University, Professor S. Kume, Tokyo University of Agriculture and Technology, and Dr. Y. Kanno, Azabu Veterinary College, for their interest and encouragement in this study. Thanks are also tendered to Professor Y. Fukuda, Juntendo University, for his valuable advice on histopathological analysis of dermal reactivity, and to Professor $T$. Suzuta, Tokyo Medical College, for his invaluable suggestions regarding the serological analysis of normal guinea pig serum.

This study was supported in part by a project research grant (No. 758) from Juntendo University School of Medicine.

\section{References}

[1] Astor, S. H., Spitler, L. E., Frick, O. L., and Fudenberg, H. H. (1973). Human leukocyte migration inhibition in agarose using four antigens: Correlation with skin reactivity. $J$. Immunol., 110, 1174-1179.

[2] Bloom, B. R., and Bennett, B. (1966). Mechanism of a reaction in vitro associated with delayed-type hypersensitivity. Science, 153, 80-82.

[3] Böyum, A. (1968). Isolation of mononuclear cells and granulocytes from human blood. Isolation of mononuclear cells by one centrifugation, and of granulocytes by combining centrifugation and sedimentation at $1 \mathrm{~g}$. Scand. J. clin. Lab. Iny., 21, Suppl. 97, 77-89.

[4] Bradley, D. J. (1974). Genetic control of natural resistance to Leishmania donovani. Nature, 250, 353-354.

[5] David, J. R., Al-Askari, S., Lawrence, H. S., and Thomas, L. (1964). Delayed hypersensitivity in vitro. I. The specificity of inhibition of cell migration by antigens. J. Immunol., 93, 264-273.

[6] Flax, M. H., and Waksman, B. H. (1962). Delayed cutaneous reactions in the rat. $J$. Immunol., 89, 496-504.

[7] George, M., and Vaughan, J. H. (1962). In vitro cell migration as a model for delayed hypersensitivity. Proc. Soc. exp. Biol. (N.Y.), 111, 514-521.

[8] Harrington, J. T., Jr., and Stastny, P. (1973). Macrophage migration from an agarose dro. 
plet: Development of a micromethod for assay of delayed hypersensitivity. J. Immunol., 110, 752-759.

[9] Kamiya, M., and Tanaka, H. (1969). Hemagglutination test in rats infected with Angiostrongylus cantonensis. Jap. J. exp. Med., 39, 593-599.

[10] Kaltreider, H. B., Soghor, D., Taylor, J. B., and Decker, J. L. (1969). Capillary tube migration for detection of human delayed hypersensitivity: Difficulties encountered with "buffy coat" cells and tuberculin antigen. $J$. Immunol., 103, 179-184.

[11] Larsh, J. E., Jr., and Weatherly, N. F. (1975). Cell-mediated immunity against certain parasitic worms. Advanc. Parasit., 13, 183-222.

[12] Lowry, O. H., Rosebrough, N. J., Farr, A. L., and Randall, R. L. (1951). Protein measurements with the Folin phenol reagent. J. biol. Chem., 193, 265-275.

[13] Mackerras, M. J., and Sandars, D. F. (1955). The life history of the rat lung,worm, Angiostrongylus cantonensis (Chen) (Nematoda: Metastrongylidae). Aust. J. Zocl., 3, 1-25.

[14] Oldstone, M. B. A., Dixon, F. J., Mitchell, G. F., and McDevitt, H. O. (197\$). Histocompatibility-linked genetic control of disease susceptibility. Murine lymphocytic choriomeningitis virus infection. J. exp. Med., 137, 1201-1212.

[15] Ouchterlony, ö. (1958). Difusion-in gel methods for immunological analysis. Progr. Allergy, 5, 1-78.

[16] Plant, J., and Glynn, A. A. (1974). Natural resistance to Salmonella infection, delayed hypersensitivity and Ir genes in different strains of mice. Nature, 248, 345-347.

[17] Rocklin, R. E. (1974). Products of activated lymphocytes: Leukocyte inhibitory factor (IIF) distinct from migration inhibitory factor (MIF). J. Immunol., 112, 1461-1466.

[18] Rocklin, R. E., Meyers, O. L., and David, J. R. (1970). An in vitro assay for cellular hypersensitivity in man. J. Immunol., 104, 95-102.
[19] Scheidegger, J. J. (1955). Une micro-méthode de l'immuno-électrophorèse. Int. Arch. Allergy, 7, 103-110.

[20] Sekikawa, H., Sato, Y., Hashimoto, T., Suzuki, T., and Otsuru, M. (1973). Immunological studies of Angiostrongylus cantonensis. (1) Sequential appearance of antibodies on the course of experimental infection. Jap. J. Parasit., 22, Suppl., 67 (in Japanese).

[21] Soulsby, E. J. L. (1972). Cell-mediated immunity responses in parasitic infections. In Immunity to Animal Parasites, Soulsby, E. J. L., editor, Academic Press, New York and London, 57-95.

[22] Thor, D. E., Jureziz, R. E., Veach, S. R., Miller, E., and Dray, S. (1968). Cell migration inhibition factor released by antigen from human peripheral lymphocytes. Nature, 219, $755-757$.

[23] Uhr, J. W. (1966). Delayed hypersensitivity. Physiol. Rev., 46, 359-419.

[24] Wakelin, D. (1975). Genetic control of immune responses to parasites: immunity to Trichuris muris in inbred and random-bred strains of mice. Parasitology, 71, 51-60.

[25] Wiener, J., Spiro, D., and Zunker, H. O. (1965). A cellular study of tuberculin sensitivity. Amer. Pathol. J., 47, 723-763.

[26] Yamashita, T., Sato, Y., Shiraki, T., Otsuru, M., and Suzuki, T. (1975). Development of Angiostrongylus cantonensis in rats, mice and guinea pigs. Jap. J. Parasit., 24, 114-121 (in Japanese with English abstract).

[27] Yoshimura, K., and Soulsby, E. J. L. (1976). Angiostrongylus cantonensis: Lymphoid cell responsiveness and antibody production in rats. Amer. J. trop. Med. Hyg., 25, 99-107.

[28] Yoshimura, K., and Yamagishi, T. (1975). Immunologic response of guinea pigs to infection with Angiostrongylus cantonensis. Jap. J. vet. Sci., 37, 585-591.

[29] Yoshimura, K., and Yamagishi, T. (1976). Reaginic antibody productions in rabbits and rats infected with Angiostrongylus cantonensis. Jap. J. vet. Sci., 38, 33-40. 


\section{Explanation of Figures}

Fig. 1. Skin reactions in guinea pig abdomen to injection of Angiostrongylus cantonensis adult worm antigen or phosphate buffered saline (PBS) following infection with $A$. cantonensis 3rd stage larvae $(\times 158)$. Sections were prepared from the animals at $44 \mathrm{hr}$ postinjection.

A: From a non-infected control guinea pig. PBS injected skin showing no reaction.

B: From the same animal as A. Antigen $(80 \mu \mathrm{g}$ of protein) injected skin showing no reaction.

C: From a guinea pig at 18 days of infection. PBS injected skin showing little cellular infiltration.

D: From the same animal as C. Antigen $(80 \mu \mathrm{g})$ injected skin showing a predominant infiltration of mononuclear cells and perivascular cuffing in the upper and deep dermis.

Fig. 2. Skin reactions in rat abdomen to injection of $A$. cantonensis adult worm antigen or phosphate buffered saline (PBS) following infection with A. cantonensis 3rd stage larvae $(\times 158)$.
Sections were prepared from the animals at $44 \mathrm{hr}$ postinjection.

A: From a non-infected control rat. PBS injected skin showing no reaction.

B: From the same rat as A. Antigen $(40 \mu \mathrm{g}$ of protein) injected skin showing no reaction.

C: From a rat at 49 days of infection. PBS injected skin showing a slight infiltration of mononuclear cells in the deep dermis.

D: From the same rat as C. Antigen $(80 \mu \mathrm{g})$ injected skin showing a predominant infiltration of mononuclear cells and perivascular cuffing in the deep dermis as well as the fat and connective tissues underlying the muscle layer.

Fig. 3. Immunoelectrophoretic pattern showing a precipitin band occurring between Angiostrongylus cantonensis adult worm antigen and normal guinea pig serum.

Remarks.

Ag: Antigen. A: Infected guinea pig serum.

B: Pooled normal guinea pig serum. 







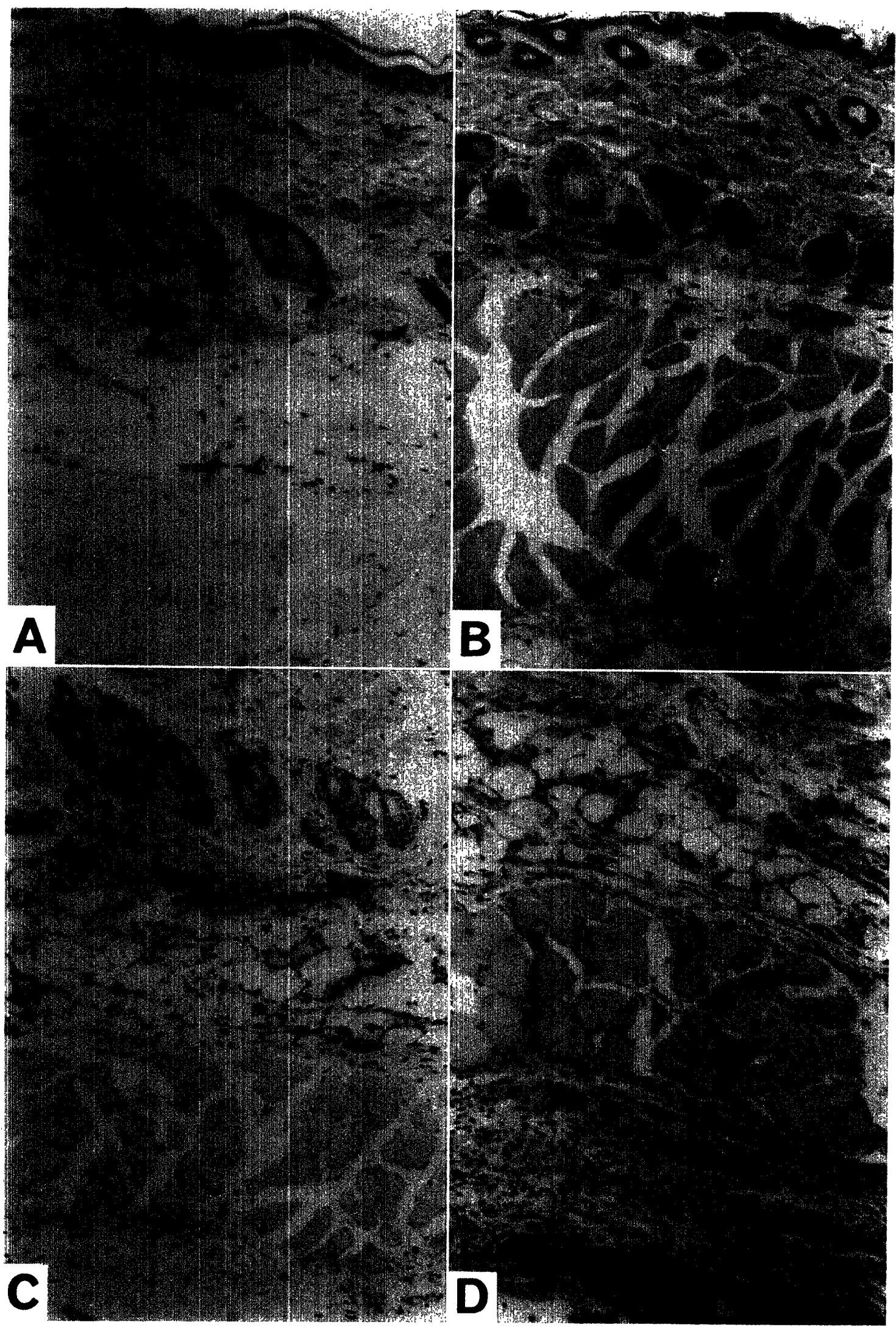






